\title{
The influence of functional ingredients on the physico-mechanical and operational properties of rubbers for water-oil-swelling sealing elements
}

\author{
(C) Evgeny N. Egorov, Nikolay F. Ushmarin, Sergey I. Sandalov, \\ Ivan S. Spiridonov, and Nikolay I. Koltsov** \\ Department of Fhysical Chemistry and Macromolecular Compounds. Chuvash State University \\ of I.N. Ulyanov. Moskovsky ave., 15. Cheboksary, 428015. Chuvash Republic. Russia. \\ Phone:+7 (8352) 45-24-68. E-mail: koltsovni@mail.ru
}

\begin{abstract}
*Supervising author; ${ }^{+}$Corresponding author
Keywords: rubbers, functional ingredients, physico-mechanical and operational properties, water-oilswelling sealing elements.

\section{Abstract}

The article investigated the effect of caoutchoucs, sevilen 11808-340, vulcanizing groups, fillers, plasticizers, ingredients of directional actions on the physical and mechanical properties (conditional tensile strength, elongation at break, hardness, rebound elasticity, tear resistance) and operational properties (changes of conditional tensile strength of rubbers after exposure to oil, weight changes after aging of rubbers in a solution of citric and hydrochloric acids, changes in the volume of rubbers after exposure to a mixture of oil and water) of two rubbers. These rubbers are developed for the manufacture of the outer and inner layers of water-oil-swellable sealing elements (WSOE) for the oil and gas industry. It has been established that rubber for the outer layer of WSOE based on butadiene-nitrile BNKS-18AMN, isoprene SKI-3 and butadiene CKD caoutchoucs, as well as rubber for the inner layer of UEN based on butadiene-nitrile BNKS-18AMN, butadiene methylstyrene SKMS-30ARK and butadiene CKD caoutchoucs possess the required physicomechanical and operational properties. It was shown that these rubbers containing a vulcanizing group sulfur + thiazole 2 MBS, sevilen 11808-340, a combination of carbon black T 900 with rosil 175, talc and chalk, petroleum resin "Sibplast", vermiculite and igloprobivnoe cloth, are characterized by improved physical-mechanical and operational properties. These rubber can be recommended as the basis for the manufacture of outer and inner layers of water-oil-swelling sealing elements.
\end{abstract}

\section{References}

[1] Sh.P. Kazimov, E.S. Abdullaeva, N.M. Radzhabov. A review of the designs of swellable packers and the possibility of their application in Azerbaijani deposits. Scientific works of NIPI NEFTEGAZ GOSOKAP. 2015. No.3. P.43-51. (russian)

[2] N.I. Koltsov, N.F. Ushmarin, A.E. Petrov, N.P. Petrov, N.N. Petrov, and S.M. Verhunov. Research of influence of technological additives on properties of rubbers on the basis of BNR new generation. Part 1. Vuhtazine RV/g-s. Butlerov Communications. 2010. Vol.19. No.2. P.79-86. ROI: jbc-02/10-19-2-79

[3] N.I. Koltsov, N.F. Ushmarin, L.G. Rogozhina, S.A. Issakova, A.V. Jarutkina, A.Y. Plehanova, and M.V. Kuzmin. Research of influence of technological additives on properties of rubbers on the basis of BNR new generation. Part 2. Elastid, oxsanoles and factice. Butlerov Communications. 2010. Vol.19. No.3. P.75-82. ROI: jbc-02/10-19-3-75

[4] N.I. Koltsov, N.F. Ushmarin, A.E. Petrov, N.P. Petrov, N.N. Petrov, and S.M. Verhunov. Research of influence of technological additives on properties of rubbers on the basis of BNR new generation. Part 3. Novantox 8 PFDA. Butlerov Communications. 2010. Vol.21. No.9. P.22-28. ROI: jbc-02/10-21-9-22

[5] N.I. Koltsov, N.F. Ushmarin, L.G. Rogozhina, S.A. Issakova, A.V. Jarutkina, A.Y. Plehanova, and M.V. Kuzmin. Research of influence of technological additives on properties of rubbers on the basis of BNR new generation. Part 4. Powder stabilizers on a basis novantox 8 PFDA. Butlerov Communications. 2010. Vol.22. No.10. P.42-50. ROI: jbc-02/10-22-10-42

[6] N.I. Koltsov, N.F. Ushmarin, N.P. Petrova, Yu.V. Vasileva, A.V. Yarutkina, N.N. Petrova, A.Y. Plekhanova, and M.V. Kuzmin. Research of influence of technological additives on properties of rubbers on the basis of BNR new generation. Part 5. Fire retardants on the basis of trichloroethylphosphate combinations. Butlerov Communications. 2012. Vol.29. No.2. P.62-68. ROI: jbc-02/12-29-2-62 
THE INFLUENCE OF FUNCTIONAL INGREDIENTS ON THE PHYSICO-MECHANICAL AND OPERATIONAL... 68-73

[7] S.I. Sandalov, M.S. Reznikov, N.F. Ushmarin, N.I. Kol'tsov. Development of thermo-aggressive rubber for packer elements. Bulletin of the Kazan Technol. University. 2014. Vol.17. No.9. P.129-132. (russian)

[8] I.S. Spiridonov, N.F. Ushmarin, S.I. Sandalov, and N.I. Koltsov. The effect of hydrogenated butadienenitrile caoutchoucs on the properties of rubber for sealing elements. Butlerov Communications. 2017. Vol.50. No.4. P.45-49. DOI: 10.37952/ROI-jbc-01/17-50-4-45

[9] I.S. Spiridonov, N.F. Ushmarin, E.N. Egorov, and N.I. Koltsov. Effect of functional ingredients on the technological properties of rubber mixtures for sealing elements. Butlerov Communications. 2017.

Vol.51. No.7. P.132-136. DOI: 10.37952/ROI-jbc-01/17-51-7-132

[10] I.S. Spiridonov, N.F. Ushmarin, S.I. Sandalov, E.N. Egorov, and N.I. Koltsov. Effect of functional ingredients on the physico-mechanical and operational properties of rubber mixtures for sealing elements. Butlerov Communications. 2018. Vol.53. No.1. P.153-157. DOI: 10.37952/ROI-jbc-01/1853-1-153

[11] I.S. Spiridonov, M.S. Illarionov, N.F. Ushmarin, S.I. Sandalov, N.I. Kol'tsov. Effect of ethylene-vinyl acetate copolymers on properties of rubber based on nitrile-butadiene rubber. News of higher educational institutions. Series "Chemistry and Chemical Technology". 2018. Vol.61. No.8. P.51-57. (russian)

[12] I.S. Spiridonov, N.F. Ushmarin, S.I. Sandalov, E.N. Egorov, M.S. Illarionova, and N.I. Koltsov. Effect of functional ingredients on the tightness of rubber thermo-aging resistant sealing elements. Butlerov Communications. 2018. Vol.55. No.9. P.72-75. DOI: 10.37952/ROI-jbc-01/18-55-9-72

[13] N.F. Ushmarin, D.V. Pelipenko, K.V. Efimov, S.I. Sandalov, and N.I. Koltsov. The influence of copolymers of ethylene with vinyl acetate on the properties of oil-swelling rubbers. Butlerov Communications. 2018. Vol.53. No.2. P.134-139. DOI: 10.37952/ROI-jbc-01/18-53-2-134

[14] E.N. Egorov, N.F. Ushmarin, S.I. Sandalov, I.S. Spiridonov, and N.I. Koltsov. The influence of functional ingredients on the technological properties of oil swelling rubber sealing elements. Butlerov Communications. 2018. Vol.54. No.5. P.159-164. DOI: 10.37952/ROI-jbc-01/18-54-5-159

[15] E.N. Egorov, E.G. Efimovsky, N.F. Ushmarin, S.I. Sandalov, I.S. Spiridonov and N.I. Kol'tsov. The influence of functional ingredients on the physico-mechanical and operational properties of rubbers for the oil swelling sealing elements. Butlerov Communications. 2018. Vol.55. No.8. P.146-150. DOI: 10.37952/ROI-jbc-01/18-55-8-146

[16] M.A. Vaniev, N.V. Sychev, S.S. Lopatina, N.V. Soldatova, V.Yu. Shiyanov, E.V. Bryuzgin. Development of water swellable elastomers for packer equipment. Bulletin of Volgograd State Technical University. 2016. No.12. P.74-80. (russian)

[17] S.S. Lopatina, M.A. Vaniev, D.A. Nilidin, N.V. Sychev, E.V. Bryuzgin, S.Yu. Onokolov. Influence of temperature on water swelling of rubbers. Bulletin of Volgograd State Technical University. 2018. No.4. P.120-123. (russian)

[18] E.N. Egorov, N.F. Ushmarin, S.I. Sandalov, I.S. Spiridonov, and N.I. Koltsov. The influence of functional ingredients on the technological properties of water-oil-swelling rubber sealing elements. Butlerov Communications. 2019. Vol.57. No.1. P.95-100. DOI: 10.37952/ROI-jbc-01/19-57-1-95 